\title{
Pemuliaan Tanaman Nilam (Progestemon cablin) Lokal Melalui Perkembangbiakan Vegetatif
}

\author{
Hermin Pancasakti Kusumaningrum**) ${ }^{11}$ Endang Dwi Purbajanti ${ }^{2)}$ dan Agus Setiadi ${ }^{3)}$ \\ 1) Laboratorium Genetika, Jurusan Biologi, Fakultas Matematika dan Ilmu Pengetahuan Alam, \\ 2) Laboratorium Ekologi dan Produksi Tanaman, Jurusan Pertanian, Fakultas Pertanian dan Peternakan, \\ 3) UniversitasDiponegoro, Jl. Prof. Soedarto, UNDIP, Tembalang, Semarang. 50275. \\ 3) Laboratorium Manajemen Agribisnis, Jurusan Pertanian, Fakultas Pertanian dan Peternakan, Universitas \\ Diponegoro, Jl.Prof. Soedarto, UNDIP, Tembalang, Semarang. 50275.
}

\begin{abstract}
Patchouli essential oil is an dominant product from Batang but its production has not been able to meet export needs. The main problem in the production of essential oil of patchouli is limited amount of seeds and dry season effect on the growth of patchouli. On the other hand, society units of patchouli essential oil is very dependent on the availability of raw materials of patchouli. Searching of patchouli local varieties must develop in order to encourages of sustainibility of patchouli production. The purpose of this activity is search and propagate patchouli plant from local varieties that can survive in different seasons of the year according to the climatic conditions of Batang. The study was conducted with the search and propagation of patchouli plant varieties used by farmers in Batang which is Sidikalang varieties and local varieties originating from Batang region and the surrounding area. Furthermore, the vegetative propagation using cuttings will be use followed by its growth observation during dry and rainy season. Results showed that the activities of patchouli plant local varieties of Bandungan, Kendal and Batang showed the best growth in the dry season.
\end{abstract}

Key words: patchouli, vegetatif growth, essential oil.

\begin{abstract}
Abstrak
Minyak atsiri nilam merupakan produk unggulan Kabupaten Batang yang saat ini produksinya belum mampu memenuhi kebutuhan ekspor. Permasalahan utama dalam produksi minyak atsiri nilam adalah keterbatasan bibit dan musim panas yang berkepanjangan yang berpengaruh terhadap pertumbuhan nilam. Disisi lain, UKM dan unit penyulingan minyak atsiri nilam sangat bergantung pada ketersediaan bahan baku tanaman nilam. Hal ini mendorong upaya untuk pencarianndan pengembangan nilam varietas unggul maupun lokal yang mampu bertahan sepanjang tahun. Tujuan dari kegiatan ini adalah pencarian dan perbanyakan tanaman nilam varietas unggul maupun lokal yang mampu bertahan dalam berbagai musim sepanjang tahun sesuai dengan kondisi iklim Kabupaten Batang. Penelitian dilakukan dengan pencarian dan perbanyakan tanaman nilam varietas unggul yang biasa digunakan petani nilam di Batang yaitu nilam varietas Sidikalang dan varietas lokal yang berasal dari Kota Batang maupun daerah sekitarnya. Selanjutnya dilakukan perbanyakan secara vegetatif menggunakan stek dan diamati pertumbuhannya aselama musim panas khusunya dan musim hujan. Hasil kegiatan memperlihatkan bahwa tanaman nilam varietas lokal dari Bandungan, Kendal dan Batang memperlihatkan pertumbuhan terbaik pada musim panas.
\end{abstract}

Kata kunci : nilam, perbanyakan vegetatif, atsiri

\section{PENDAHULUAN}

Indonesia sangat kaya dengan berbagai ragam tanaman. Tanaman nilam Indonesia (Pogostemon sp.) merupakan penghasil atsiri sudah dikenal dunia sejak 65 tahun yang lalu, volume ekspor minyak atsiri selalu mengalami peningkatan. Minyak atsiri nilam
Indonesia telah memberikan pangsa pasar lebih dari 90\% kebutuhan dunia atau sekitar 35-40\% dari total nilai ekspor minyak atsiri (BPPS, 2013). Perkembangan industri komestik, parfum, dan farmasi menjadi pemicu meningkatnya kebutuhan minyak nilam baik di tingkat nasional maupun internasional (Emmyzar dan Ferry, 2004) 
Komponen utama minyak nilam adalah patchouli alcohol sebesar $45 \%$ sampai 50\%). Bahan kimia lain dalam nilam yang ditemukan dalam nilam adalah patchoully camphor, benzaldehyde, eugenol, cinnamic aldehyde, seychellene, aciphyllene, $a$ bulnesene, $\alpha$-, $\quad \beta$ and $\delta$-patchoulene patchoulene, , $\beta$-caryophyllene, $\alpha$ - and $\delta$ guaiene, pogostone $\delta$-cardinene, germacrene- $\mathrm{B}$, $\alpha$-guaiene, $\quad \delta$-guaiene, $\quad \beta$-elemene, frieddelin. trans-caryophyllene, epifriedelinol, pachypodol, retusine, oleanolic acid, $\beta$ - sitosterol daucosteroldan pogostol. Analisis GC dan GC/MS terhadap nilam Indonesia menemukan unsur lain yaitu $\alpha$-pinene, pogostol, $\beta$-pinene, aciphyllene, limonene, cycloseychellene, $\delta$ elemene,7-epi-a-selinene, $\quad \alpha$-copaene, norpatchoulenol, a-patchoulene, 1,10-epoxy-11bulnesene, nortetrapatchoulol, caryophyllene oxide, patchoulenone, seychellene, $\quad \beta$ caryophyllene, $\gamma$-gurjunene, 9-oxopatchoulol, a-humulene, a-patchoulene, isopatchoulenone, dan germacrene $D$. Analisis kandungan kimia terhadap sampel nilam dari Cina memperlihatkan kandungan utama beberapa senyawa pada batang dan daun yaitu senyawa pogostone (30.99\% pada batang, $21.31 \%$ pada daun), patchouli alcohol $(10.26 \%$ pada batang, $37.53 \%$ pada daun), trans-caryophyllene (4.92\% pada batang, $6.75 \%$ pada daun), $\alpha$ guaiene $(2.27 \%$ pada batang, $6.18 \%$ pada daun) dan seychellene $(1.56 \%$ pada batang, $1.99 \%$ pada daun (Ketaren. 1985)

Minyak nilam memiliki banyak fungsi karena kandungan bahan yang dimilikinya yaitu sebagai bahan antimikrobia terhadap 20 bakteri, virus dan 12 fungi antara lain Acenitobacter baumanii, Aeromonas veronii, Candida albicans, Enterococcus faecalis, E. aerogenes, B. subtilis, Escherichia coli, Klebsiella pneumonia, Pseudomonas aeruginosa, Salmonella enteric, Helicobacter pylori, Streptococcus, Staphyllococcus aureus, Virus influenza H1N1 dan H2N2 (Chao et al,, 2008; Swamy and Sinniah, 2015) Selain itu minyak nilam digunakan sebagai obat HIV/AIDS, tumor dan kanker, sakit perut, pembekuan darah, antijerawat, eksem dan kulit pecah-pecah, obat ketombe, insektisida dan sebagai antioksidan (National Cancer Institute,
2012). Minyak nilam juga dapat mengurangi peradangan, mengurangi kegelisahan dan depresi, atau membantu penderita insomnia serta bersifat afrodisiak (Bakkali et al., 2010; Djilani and Dicko, 2012).

Tanaman nilam merupakan tanaman perdu berukuran sekitar setengah sampai satu meter. Pertumbuhan nilam membutuhkan intensitas cahaya yang tidak terlalu kuat karena mudah layu bila kekurangan air. Perkembangbiakan tanaman nilam. Tanaman nilam mempunyai batang berkayu berbentuk segi empat. Daun hijau tersusun dalam pasangan berlawanan. Berbentuk bulat lonjong, panjang $10 \mathrm{~cm}$, lebar $8 \mathrm{~cm}$, dengan ujung agak meruncing. Tangkai daun sekitar $4 \mathrm{~cm}$ berwarna hijau kemerahan. Nilam bisa tumbuh di mana saja, baik di dataran rendah maupun dataran tinggi $(0-1.200 \mathrm{~m} \mathrm{dpl})$ namun tumbuh baik pada $200-600 \mathrm{~m}$ dpl. Kondisi pertumbuhan lainnya yang dibutuhkan nilam adalah curah hujan 2.000 $-3.500 \mathrm{~mm} / \mathrm{th}$, garis lintang $20^{\circ} \mathrm{LS}-20^{\circ} \mathrm{LU}$, bulan kering ( $\mathrm{CH}<60 \mathrm{~mm} / \mathrm{bln}) 3$ bulan, suhu maksimum $30-32^{\circ} \mathrm{C}$, minimum $18-21^{\circ} \mathrm{C}$. dengan suhu optimal $27^{\circ}$ C. Perbanyakan biasanya dilakukan secara vegetatif. Minyak atsiri nilam merupakan produk unggulan Kabupaten Batang yang saat ini produksinya belum mampu memenuhi kebutuhan ekspor. Nilai ekonomi minyak atsiri Batang cukup tinggi dengan pangsa pasar yang luas, sudah tersedia, sangat terbuka dan cepat berkembang dan sangat membantu pendapatan daerah. Permasalahan utama dalam produksi minyak atsiri nilam adalah kuantitas dan kualitas bibit yang rendah, usia tanaman yang semakin tua, mesin produksi dengan skala terbatas dan umur yang sudah tua, jenis produk yang sedikit karena skala produksi yang belum meningkat. Hal ini menunjukkan kecenderungan kuantitas dan kualitas produksi minyak atsiri yang dapat diekspor akan semakin menurun bila tidak segera dicari upaya untuk mengatasi permasalahan tersebut. Kabupaten Batang mengalami kesulitan dalam penyediaan bibit nilam pada musim panas. Nilam mudah layu jika terkena sinar matahari langsung atau kekurangan air. Karakterisasi nilam tersebut membuat ketersediaannya cukup sulit pada daerah di Indonesia yang terkenan intensitas tinggi 
seperti di daerah Batang apalagi sepanjang musim panas pada tahun 2015. Banyak sekali nilam yang mati akibat kekurangan air termasuk nilam varietas unggul dari Aceh seperti varietas Sidikalang dan varietas Lhoksemauwe.

Nilam Jawa (P. heyneani), merupakan nilam asli India yang banyak tumbuh di hutan di Pulau Jawa dan memiliki kualitas PA yang lebih rendah dibanding tanaman nilam yang banyak ditemukan di Aceh ( $P$. patchouli atau $P$. cablin Benth, atau $P$. mentha). Nilam $P$. patchouli berasal dari Filipina, tapi dikembangkan di Malaysia, Madagaskar, Paraguay, Brasil, dan Indonesia. $P$. patchouli yang dikenal dengan Nilam Aceh banyak dibudidayakan secara komersial dan Daerah Istimewa Aceh, terutama Aceh Selatan dan Tenggara menjadi sentra tanaman nilam terluas di Indonesia diikuti oleh Sumatra Utara (Nias, Tapanuli Selatan), Sumatra Barat, Bengkulu, Lampung, Jawa Tengah (Banyumas, Banjarnegara), dan Jawa Timur (Tulungagung). Varietas lainnya adalah $P$. hortensis, atau nilam sabun (minyak atsirinya bisa untuk mencuci pakaian) banyak dijumpai di daerah Banten, Jawa Barat dimana morfologinya mirip Nilam Jawa tapi mempunyai bunga.

Pencarian dan pengembangan nilam varietas unggul yang mampu bertahan dalam setiap musim sepanjang tahun merupakan upaya yang perlu dilakukan untuk menjaga ketersediaan bahan baku minyak atsiri nilam secara terus menerus. Tujuan dari kegiatan ini adalah pencarian dan perbanyakan tanaman nilam varietas unggul maupun lokal yang mampu bertahan dalam berbagai musim sepanjang tahun sesuai dengan kondisi iklim Kabupaten Batang. Kegiatan dilakukan melalui pencarian dan pemuliaan tanaman nilam varietas lokal yang biasa digunakan petani nilam di Batang yaitu nilam varietas Sidikalang dan varietas lokal yang berasal dari Kota Batang maupun daerah sekitarnya dan optimasi pertumbuhannya. Kegiatan ini utamanya diharapkan akan memperoleh tanaman nilam yang mampu tumbuh dengan kondisi air terbatas pada musim panas di daerah Batang. Pembibitan nilam menjadi satu hal yang penting untuk dilakukan agar ada bibit-bibit nilam yang siap untuk ditanam dan dibudidayakan. Perbanyakan tanaman nilam lebih banyak dilakukan secara vegetatif agar memperoleh sifat yang sama dengan induknya. Perbanyakan tersebut merupakan suatu caracara perbanyakan atau perkembangbiakan tanaman dengan menggunakan bagian-bagian tanaman seperti batang, cabang, ranting, pucuk, daun, umbi dan akar, untuk menghasilkan tanaman yang baru, yang sama dengan induknya. Prinsip perbanyakan vegetatif adalah merangsang tunas adventif yang ada dibagian-bagian tersebut agar berkembang menjadi tanaman sempurna yang memiliki akar, batang, dan daun sekaligus. Tanaman yang berasal dari perbanyakan secara vegetatif lebih cepat berbunga dan berbuah (Syukur dkk, 2002; Jaenicke and Beniest, 2002; Raharja dan Wiryanta, 2003; Mangoendidjojo, 2003; Kementerian Pendidikan Nasional, 2011).

\section{BAHAN DAN METODE}

Bahan yang digunakan dalam kegiatan ini ada 4 jenis bibit nilam yaitu nilam varietas Sidikalang ( $P$. cablin Benth) dari Balittro, nilam varietas lokal dari Batang, nilam varietas Sidikalang yang diaklimatisasi di Bandungan dan Sukorejo. Proses pembibitan secara vegetatif dan pesemaian menggunakan stek dari batang ataupun cabang dari pohon nilam. Panjang untuk bibit adalah sekitar 15 hingga $23 \mathrm{~cm}$ dengan mata tunas. Setek ataupun bibit ditanam dengan posisi miring dengan sudut $45^{\circ}$ sedalam $10 \mathrm{~cm}$ dengan jarak tanam sekitar 10 kali $10 \mathrm{~cm}$. Bibit-bibit nilam akan siap untuk dipindahkan dalam 3 hingga 4 minggu.

Perbanyakan nilam varietas Sidikalang Aceh dan varietas lokal Batang dilakukan di green house menggunakan stek dan tidak ditumbuhkan menggunakan naungan. Perbanyakan nilam varietas Sidikalang yang telah diaklimatisasi di Sukorejo dan Bandungan dilakukan di green house menggunakan stek dan ditumbuhkan dalam naungan. Stek yang telah mengalami pertumbuhan lalu ditanam di demplot BP3K di Blado Batang dan di daerah Bawang Kabupaten Batang. Perbanyakan dilakukan secara secara vegetatif menggunakan stek dan diamati pertumbuhannya selama musim panas khususnya dan musim hujan 


\section{HASIL DAN PEMBAHASAN}

Perbanyakan tanaman secara vegetative nilam umumnya dilakukan dengan cara stek seperti kegiatan yang telah dilakukan pada gambar 1

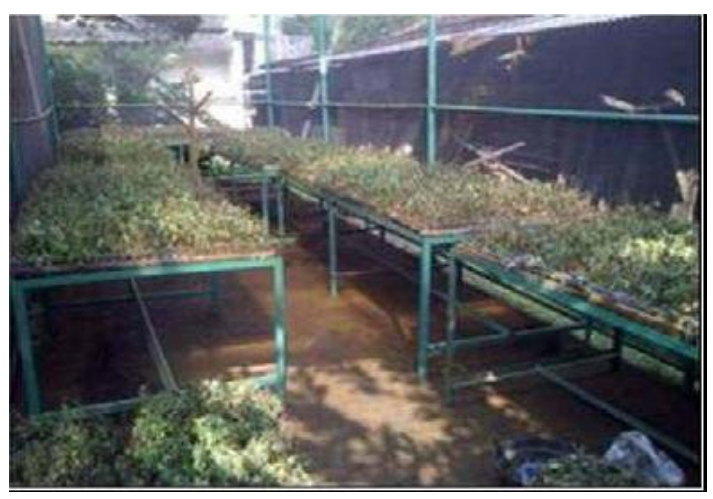

Gambar 1. Stek Nilam Kultivar Sidikalang

Kandungan kimia pada nilam bergantung pada berbagai faktor. Faktor tersebut antara lain adalah lokasi geografis tempat tumbuh nilam, waktu pemanenan, bagian tanaman yang dipanen, dan metode pemrosesan. Lokasi tempat tumbuhnya nilam di Indonesia sangat tersebar di berbagai tempat seperti Ciamis, Garut, Kuningan, Kulonprogo, Aceh, Malang dan Batang. Kabupaten Batang memiliki daerah penanaman nilam yang cukup luas karena kondisi geografis yang mendukung karena sebagian besar wilayah Kabupaten Batang merupakan perbukitan dan pegunungan (Ambarsari dkk, 2009). Di bagian selatan terdapat Dataran Tinggi Dieng dengan puncaknya Gunung Prau (2.565 meter). Kabupaten Batang terletak pada $6^{\circ} 51^{\prime} 46^{\prime \prime}$ sampai $7^{\circ} 11^{\prime} 47^{\prime \prime} \mathrm{LS}$ dan antara $109^{\circ} 40^{\prime} 19^{\prime \prime}$ sampai $110^{\circ} 03^{\prime} 06^{\prime \prime}$ Bujur Timur di pantai utara Jawa Tengah. Ketinggian daerah di Kabupaten Batang adalah $600-800$ dpl dengan curah hujan umumnya $2000-6307 \mathrm{~mm} / \mathrm{th}$, suhu lingkungan

$24-32^{\mathrm{O}} \mathrm{C}$. Jenis tanah yang dominan adalah latosol yang sangat dibutuhkan untuk menghasilkan pertumbuhan nilam yang terbaik (Kabupaten Batang, 2014).

Tanaman nilam yang tumbuh di Batang umumnya varietas Sidikalang dari Aceh selain nilam lokal dari Batang sendiri yang diduga merupakan Nilam Jawa. Varietas sidikalang merupakan salah satu hasil ekplorasi nilam oleh Balittro yang menemukan bermacammacam tipe nilam yang berbeda karakter morfologinya, kandungan minyak, sifat fisika kimia minyak dan sifat ketahanannya terhadap penyakit dan kekeringan. Nilam Aceh berkadar minyak tinggi (> 2,5\%) sedangkan nilam Jawa rendah (<2\%) (Arpi dkk, 2011). Balittro telah mengoleksi 28 nomor nilam, dimana tahun 2005 telah dilepas 3 varietas unggul dari Aceh berdasar nama daerah asal yaitu Tapak Tuan, Lhokseumawe dan Sidikalang. Tapak Tuan unggul dalam produksi dan kadar patchouli alkohol. Lhokseumawe kadar minyaknya tinggi sedangkan Sidikalang toleran terhadap penyakit layu bakteri dan nematoda (Darwis, 2004). Nilam Aceh merupakan tanaman introduksi, diperkirakan daerah asalnya Filipina atau Semenanjung Malaysia, masuk ke Indonesia lebih dari seabad yang lalu. Setelah sekian lama berkembang di Indonesia, tidak tertutup kemungkinan terjadi perubahanperubahan dari sifat asalnya (Nuryani dkk, 2007). Hal yang sama terjadi pada varietas unggul nilam Aceh yang ditanam di Batang dan daerah Jawa Tengah. Karakter genetik yang unggul dapat meningkat atau menurun karena efek dari lingkungan dan kondisi geografis. Beberapa daerah di Jawa telah melakukan aklimatisasi dan pemuliaan tanaman nilam yang berasal dari Aceh dan jenis yang dominan adalah varietas Sidikalang. Hasil aklimatisasi dan pemuliaan tersebut diperlihatkan Gambar 2. 

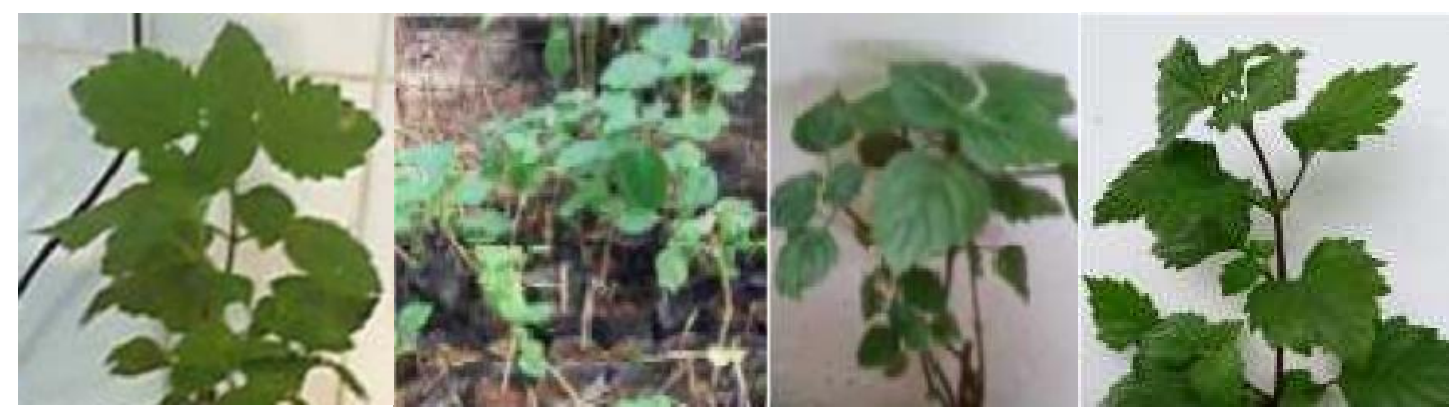

Gambar 2. Tanaman nilam kultivar lokal : (1) Batang (2) Sidikalang (3) Bandungan (4) Sukorejo

Ciri-ciri spesifik yang biasa digunakan dalam membedakan nilam Jawa dan nilam Aceh secara visual yaitu pada daunnya. Permukaan daun nilam Aceh halus sedangkan nilam Jawa kasar. Berdasarkan atas hasil pengamatan, aklimatisasi dan pemuliaan yang telah dilakukan dalam kegiatan ini seperti diperlihatkan pada Gambar 2. Memperlihatkan bahwa nilam lokal Batang mempunyai permukaan daun yang halus dibanding varietas Sidikalang dari Balittro. Permukaan daun nilam varietas Sidikalang agak kasar serupa dengan varietas nilam dari Bandungan dan Sukorejo. Selain itu tepi daun nilam Aceh bergerigi tumpul, pada nilam Jawa bergerigi runcing, ujung daun nilam Aceh runcing, nilam Jawa meruncing. Berdasarkan atas pengamatan terlihat bahwa hanya nilam Sukorejo yang memperlihatkan karakter seperti nilam Jawa padahal nilam tersebut berasal dari varietas Sidikalang Aceh. Bila kita amati lebih jauh terhadap nilam yang berasal dari Sukorejo maka kita akan mendapati beberapa perbedaan yang diperlihatkan pada Gambar 3.

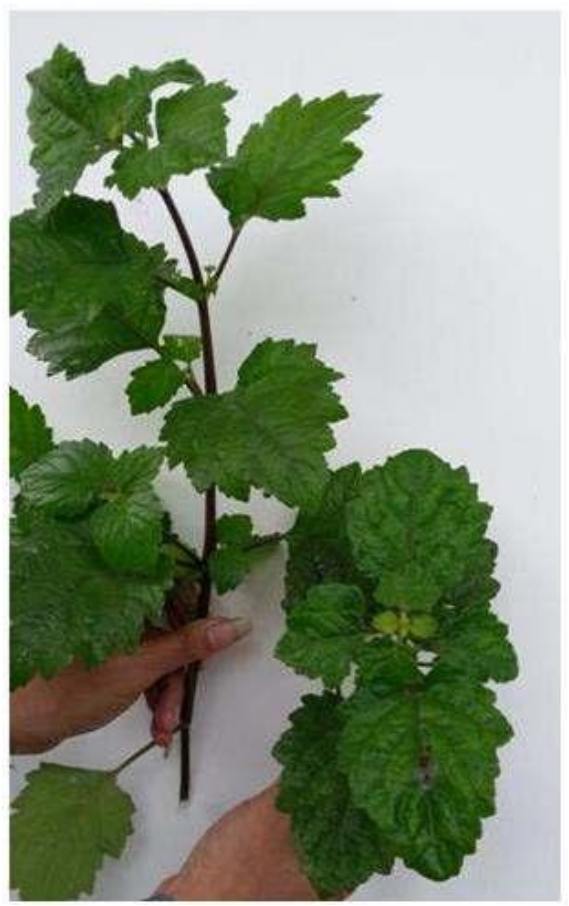

Gambar 3. Nilam asal Sukorejo yang tumbuh dalam intensitas cahaya rendah (kiri) dan intensitas cahaya tinggi (kanan) dalam skebun pesemaian yang sama

Hasil yang diperlihatkan pada Gambar 3 meninujukkan bahwa pada intensitas cahaya rendah, tanaman nilam akan tumbuh lebih tinggi, batang lebih panjang dan bentuk daun yang lebih meruncing dan permukaan daun yang lebih halus. Di sisi lain, nilam yang ditumbuhkan dalam kebun pesemaian yang sama dengan intensitas cahaya matahari yang lebih tinggi akan tumbuh lebih 
rendah, batang lebih pendek dan bentuk daun yang lebih membulat dengan permukaan daun akan lebih kasar. Hasil pemuliaan memperlihatkan bahwa karakterisasi nilam berdasarkan atas morfologi menjadi kurang valid karena sangat bergantung pada faktor lingkungan.

Tanaman nilam adalah tanaman penghasil minyak atsiri, oleh sebab itu pemuliaan suatu varietas akan menentukan keunggulannya terkait dengan produksi, kadar dan mutu minyak atsiri. Karakter lain yang diamati selama kegiatan pemuliaan memperlihatkan bahwa nilam varietas Sidikalang yang ditanam langsung dari stek dalam polybag di bawah naungan dan tidak menggunakan sungkup seperti diperlihatkan pada Gambar 4. ternyata kurang tahan terhadap serangan bekicot sehingga menyebabkan kematian sebesar 60\% dari 30.000 bibit, Selain itu tanaman yang tersisa dan sudah bertunas kemudian mengalami kelayuan sehingga hanya tersisa kurang dari $1 \%$ dalam polybag.

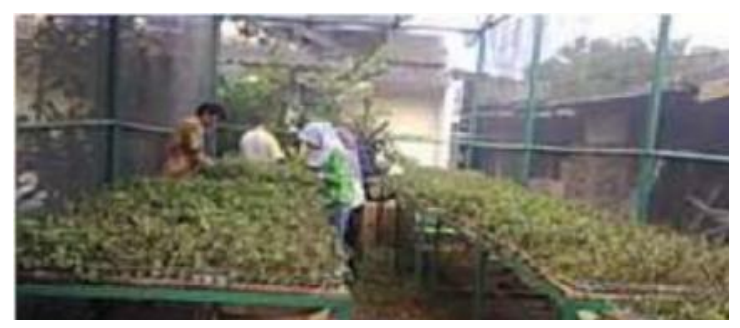

Gambar 4. Penanaman stek nilam varietas Sidikalang di green house

Di sisi lain penanaman varietas lokal dari Batang dengan perlakukan yang sama memperlihatkan pertumbuhan yang pesat dan tahan terhadap penyakit. Hasil yang diperoleh tersebut bertentangan dengan karakter varietas Sidikalang yang toleran terhadap penyakit seperti layu bakteri dan nematoda yang merupakan salah satu indikator penentu sehingga varietas Sidikalang digolongkan dalam varietas unggul (Sriwati dkk, 1999; Sukamto dkk, 2014). Hasil yang diperoleh memperlihatkan bahwa selain faktor genetik maka proses budidaya, lingkungan, panen dan pasca panen sangat menentukan dalam suatu proses pemuliaan
Pemuliaan varietas lokal Bandungan telah dilakukan menggunakan stek dalam polybag di bawah naungan dan menggunakan sungkup telah memperlihatkan pertumbuhan yang baik setelah dipindahkan di lapangan. Hasil yang diperoleh tersebut diperlihatkan pada Gambar 5 dan Gambar 6. Pemuliaan lebih lanjut terhadap bibit tanaman nilam dari varietas ukorejo juga memperlihatkan hasil yang sama dengan varietas Bandungan. Hasil yang diperoleh tersebut memperlihatkan bahwa varietas Sidikalang telah mengalami aklimatisasi dan adaptasi dengan kondisi geografis di Batang, Bandungan dan Sukorejo dan mempunyai ketahanan penyakit yang lebih tinggi dibanding tanpa aklimatisasi dan pemuliaan

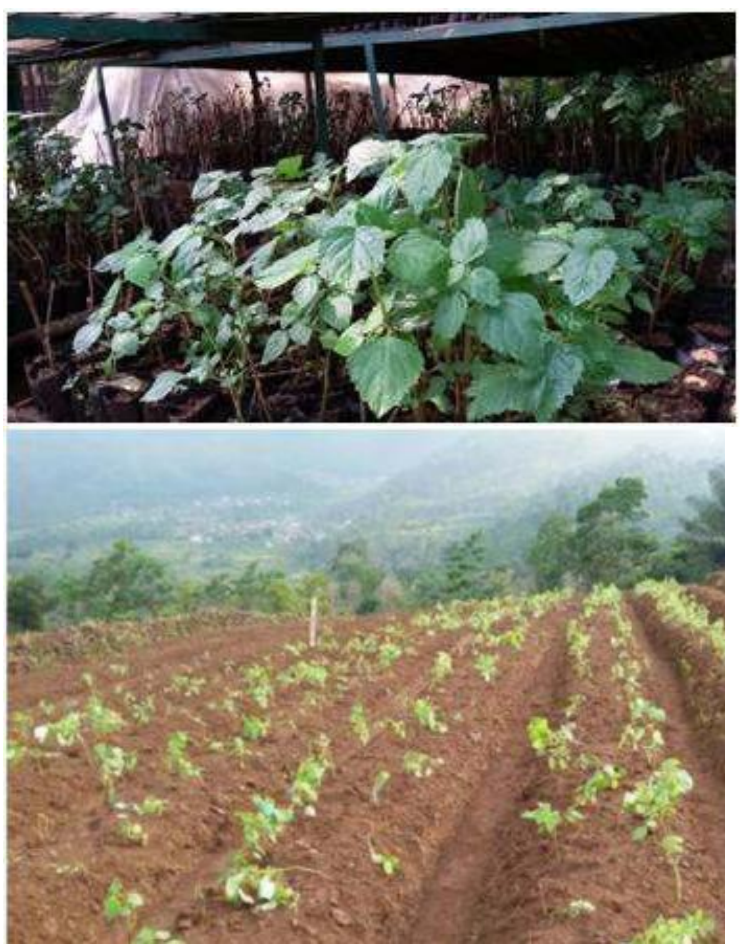

Gambar 5. Penanaman stek nilam varietas Bandungan di sungkup (atas) dan pemindahannya di lapangan di daerah Bawang Batang (bawah) 


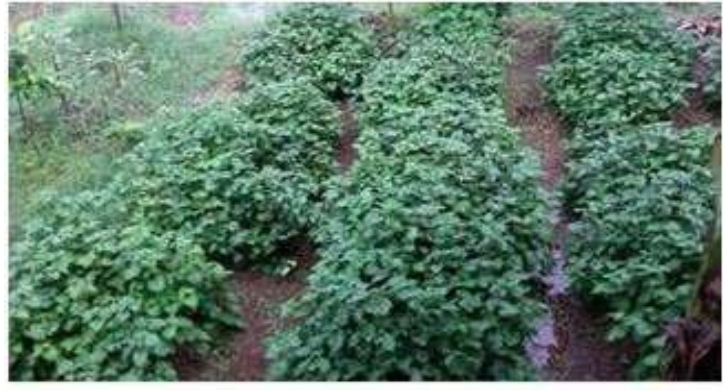

Gambar 6. Penanaman nilam varietas Sukorejo didaerah Blado Batang

Hasil yang diperoleh dalam pemuliaan beberapa varietas nilam telah memperlihatkan bahwa pemuliaan merupakan suatu upaya yang diperlukan dalam meningkatkan kualitas bibit dan tanaman nilam

\section{KESIMPULAN}

Pencarian dan pemuliaan tanaman nilam varietas unggul maupun lokal yang mampu bertahan dalam berbagai musim sepanjang tahun sesuai dengan kondisi iklim Kabupaten Batang telah memperoleh varietas Batang, Sukorejo dan Bandungan yang memperlihatkan karakter pertumbuhan yang lebih baik dari karakter induknya yaitu nilam varietas Sidikalang.

\section{UCAPAN TERIMAKASIH}

Tim Peneliti mengucapkan terimakasih pada Dibiayai oleh Direktorat Penelitian dan Pengabdian kepada Masyarakat (Ditlitabmas) Kementerian Riset, Teknologi dan Pendidikan Tinggi

\section{DAFTAR PUSTAKA}

Ambarsari, I., D.A.A. Choliq dan A. Elisabeth. 2009. Keragaan usaha pengolahan minyak nilam di tingkat petani Kabupaten Batang Jawa Tengah. Seminar nasional inovasi untuk petani dan peningkatan daya saing produk pertanian. ISBN 978-979-3450-28 b. BPTP Jawa Tengah : 542-549

Badan Pusat Statistik. 2013. Perkembangan Beberapa Indikator Utama Sosial- Ekonomi Indonesia. Trends of Selected Socio-Economic Indicators of
Indonesia. Februari February 2013, Katalog BPS : 3101015, Statistics Indonesia

Bakkali, F., S. Averbeck a, D. Averbeck and M. Idaomar. 2010. Biological effects of essential oils . A review. Institut CurieSection de Recherche, UMR2027 CNRS/IC, LCR V28 CEA, Ba t.110, Centre Universitaire, 91450 orsay Cedex France , 446-476

Chao, S, G. Young, C. Oberg and Karen.2008. Inhibition of methicillin- resistant Staphylococcus aureus (MRSA) by essential oils. Flavour and Fragrance Journal. Publ online in Wiley InterScience (www.interscience. wiley.com) DOI: 10.1002/ffj. 1904. Copyright (C) 2008 John Wiley \& Sons, Ltd. Flavour Fragr. J.; 23: 444-449

Darwis, M. 2004. Jenis-jenis hama dan serangannya pada Tanaman Nilam. Balai Penelitian Tanaman Rempah dan Obat. 7581

Djilani A. dan A. Dicko. 2012. The therapeutic benefits of essential oils. www.intechopen.com : 155-178

Emmyzar dan Y. Ferry. 2004. Pola budidaya untuk peningkatan produktifitas dan mutu minyak nilam (Pogostemon cablin benth). Balai penelitian tanaman rempah dan obat. perkembangan teknologi tro vol. xvi, no. 2

Jaenicke, J. and Beniest, J. 2002. Vegetative Tree Propagation in Agroforestry. ICRAFT. Nairobi. Kenya.

Kabupaten Batang, 2014. Daerah Dalam Angka (DDA) 2014.

Kementerian Pendidikan Nasional. 2011. Dasardasar Perbanyakan Tanaman secara Vegetatif. Diklat Teknis Peningkatan Kompetensi Pendidik Produktif. Bidang Perbenihan Tanaman (Perbanyakan Tanaman Secara Vegetatif) Bagi Guru SMK Pertanian seluruh Indonesia (Jenjang Lanjutan). Badan Pengembangan Sumberdaya Manusia Pendidikan dan Penjaminan Mutu Pendidikan, Pusat Pengembangan dan Pemberdayaan Pendidik dan Tenaga Kependidikan Pertanian

Ketaren. S. 1985. Pengantar Teknologi 
Minyak Atsiri . Balai Pustaka.

Mangoendidjojo, W. 2003. Dasar-Dasar Pemuliaan Tanaman. Kanisius. Yogyakarta

National Cancer Institute. 2012. Aromatherapy and Essential Oils

Nuryani, Y. Emmyzar, dan A. Wahyudi. 2007. Teknologi Unggulan Nilam Perbenihan dan Budidaya Pendukung Varietas Unggul. Badan Penelitian dan Pengembangan Pertanian. Pusat Penelitian dan Pengembangan Perkebunan

Raharja, PC. dan Wiryanta, W. 2003. Aneka Cara Memperbanyak Tanaman. Agro Media Pustaka. Jakarta.

Sriwati, R., M.S. Sinaga., A.M. Adnan dan I. Mustika. 1999. Ketahanan beberapa kultivar Nilam (Pogostemon cablin Bent.) terhadap Pratylenchus brachyurus (Godfrey) Filipjev. \& Stekhoven. Buletin Hama dan Penyakit Tumbuhan 11(2):4855.

Sukamto, M. Syakir dan M. Djazuli. 2014.
Pengendalian penyakit budok pada tanaman nilam dengan agensia hayati dan pembenah tanah. Prosiding Seminar Nasional Pertanian Organik. Bogor 18-19 Juni 2014:32-328

Swamy, M.K and U.R. Sinniah. 2015. A Comprehensive Review on the Phytochemical Constituents and Pharmacological Activities of Pogostemon cablin Benth.: An Aromatic Medicinal Plant of Industrial Importance. Review ISSN 1420-3049.

www.mdpi.com/journal/molecules.. doi:10.3390/molecules 20058521. Molecules (20) : 8521-8547

Syukur, M., Sujiprihati, dan R. Yunianti. 2002. Teknik Pemuliaan Tanaman. Penebar Swadaya. H.115-173 